\title{
Osmotic Adjustment and the Accumulation of Organic Solutes in Whole Cells and Protoplasts of Saccharomyces cerevisiae
}

\author{
By AMANDA J. MEIKLE, ROBERT H. REED AND GEOFFREY M. GADD* \\ Department of Biological Sciences, University of Dundee, Dundee DDI 4HN, UK
}

(Received 25 April 1988; revised 28 June 1988)

\begin{abstract}
In the presence of a suitable carbon source, whole cells and protoplasts of Saccharomyces cerevisiae synthesized glycerol as a compatible organic solute in response to increased external osmotic pressure. Boyle-van't Hoff plots showed that protoplasts, and non-turgid cells, exhibited a linear relationship between volume and the external osmotic pressure (i.e. they behaved as near-ideal osmometers), and that both protoplasts and cells have a component which is not osmotically responsive - the non-osmotic volume (NOV). Glycerol levels in whole cells and protoplasts were elevated by increased external osmotic pressure over a similar time-scale to the period of exponential cell growth, reaching a maximum value at 6-12 $\mathrm{h}$ and declining thereafter. This suggests that the restoration of turgor pressure in whole cells was not the sole regulator of glycerol accumulation. Stationary phase whole cells had negligible levels of intracellular glycerol after growth in a medium of raised osmotic pressure. However, intracellular trehalose synthesis in these cells began earlier and reached a higher maximum level than in basal medium. Once exponential growth had stopped, cell turgor and internal osmotic pressure decreased somewhat. These new, lower values may be determined by the extent of trehalose accumulation in stationary phase cells.
\end{abstract}

\section{INTRODUCTION}

The ability of organisms to grow under conditions of elevated osmotic pressure has received much attention with respect to general aspects of physiology and biochemistry (Brown, 1976, 1978; Jennings, 1983; Munns et al., 1983; Vreeland, 1987), food science (Onishi, 1963), and industrial potential (Ben-Amotz \& Avron, 1983).

During growth, a walled cell will have an internal osmotic pressure greater than the external osmotic pressure. The consequent tendency for water to flow into the cell, leading to an increase in volume, is opposed by the stretched cell wall, generating a turgor pressure within. Since the elasticity of the cell wall varies in different organisms, the extension needed to generate a suitable turgor pressure may range widely for differing cell types (Nobel, 1983).

If the external osmotic pressure increases, water flows out, volume and turgor decrease and the cell shrinks until a new osmotic equilibrium is reached. Many algal cells treated in this way have been shown to recover their initial turgor (Cram, 1976). This is achieved by the accumulation of solutes, by either transport or biochemical interconversions, raising the internal osmotic pressure which leads to the flow of water into the cell and subsequent restoration of cell turgor. Such walled cells operate a system of turgor regulation.

In wall-less cells, the plasma membrane can sustain only a negligible hydrostatic pressure. Wall-less micro-organisms in a hypo-osmotic medium (such as a fresh water environment) regulate their volume using contractile vacuoles to expel excess fluid accumulated due to the osmotic imbalance between the cell interior and the external medium. In micro-organisms growing in a saline medium (such as a marine environment) the internal and external osmotic

Abbreviation: NOV, non-osmotic volume. 
pressures are effectively equal, and contractile vacuoles are not required. In response to hyperosmotic treatment wall-less organisms may regulate their volume by the accumulation of solutes within the cell, accompanied by an osmotically driven inflow of water and an increase in cell volume at an essentially constant internal osmotic pressure. Thus wall-less cells show volume regulation (Cram, 1976; Reed, 1984).

Accordingly, cell osmotic relations involve these two parameters, i.e. cell volume and cell turgor pressure. Walled micro-organisms have a certain degree of elasticity, described by the volumetric elastic modulus $(\varepsilon)$, which governs the fractional change in volume for any given change in turgor (Nobel, 1983), and therefore changes in volume and in turgor pressure must be considered when looking at the osmotic adjustment made by such cells. The elastic modulus is an important parameter in cell water relations since it determines the degree of changes in cell turgor pressure and volume caused by a given change in external osmotic pressure (Dainty, 1972).

In most organisms that grow under conditions of high osmotic pressure, the internal osmotic pressure is generated largely by the intracellular accumulation of one or more low molecular mass organic solutes. Osmotic adjustment of intracellular organic solutes has been reported for a wide range of micro-organisms, including bacteria (Measures, 1975), cyanobacteria (Reed et al., 1984a, b; Mackay, et al., 1984), fungi (Brown \& Simpson, 1972; Jennings, 1983; Gadd et al., 1984) and micro-algae (Hellebust, 1976).

Several studies have shown that osmotically stressed yeasts accumulate polyols, particularly glycerol and arabitol (Borowitzka \& Brown, 1974; Gustaffson, 1979; Jennings, 1984; Adler et al., 1985; Hocking, 1986). There are other carbohydrates which may make a considerable contribution to intracellular osmotic pressure in yeasts, but do not respond to changes in the osmolality of the external environment (Jennings, 1983). In contrast, compounds such as glycerol in Saccharomyces cerevisiae have an important role in osmotic adjustment since their intracellular concentration and absolute quantity varies with the external osmotic pressure. All known osmoresponsive solutes (or osmolytes) fit, to varying degrees, the definition of a compatible solute proposed by Brown \& Simpson (1972). Compatible solutes are low molecular mass, neutral compounds which may be accumulated to high intracellular concentrations while causing little enzyme inhibition. Not all organic compatible solutes are carbohydrates (Borowitzka, 1985); other classes include amino acids, tertiary sulphonium compounds and quaternary ammonium compounds (including betaines). Although the mechanisms of action of these compatible solutes have not been fully elucidated in all cases, Low (1985) has reviewed the current models for compatible solute function, noting that these compounds are preferentially excluded from the hydration spheres of proteins, promoting subunit assembly, stabilizing against denaturation and activating enzymes in the presence of denaturing solutes. Thus, Arakawa \& Timasheff (1985) describe the protein-preferential hydration induced by certain neutral osmolytes upon lysozyme. Le Rudulier et al. (1984) discuss the molecular biology of the osm (osmotic tolerance) genes that protect bacteria such as Escherichia coli against osmotic stress and suggest that they may work in a similar manner with respect to drought resistance. Crowe $e t$ $a l$. $(1984 a, b)$ have since shown that several carbohydrates are able to preserve membrane structure and function under conditions of desiccation.

Cells of $S$. cerevisiae accumulate osmotically significant quantities of glycerol in response to hyperosmotic shock (Edgley \& Brown, 1983; Reed et al., 1987). However the regulatory processes involved in such osmotic adjustment are, as yet, unclear. Bearing in mind that osmotic adjustment in yeast cells must involve volume and turgor pressure changes, we have studied the effects of hyperosmotic media on volume change and osmolyte accumulation in whole cells and protoplasts of $S$. cerevisiae. Since protoplasts are wall-less and are effectively non-turgid, if the restoration of a positive turgor pressure was required to control osmolyte (glycerol) accumulation then one would expect a sustained increase in protoplast internal solute levels. In contrast, an osmolyte-accumulating mechanism controlled with respect to volume would be operable. A comparison of the osmotic responses of whole cells and protoplasts may therefore be useful in assessing the significance of turgor and/or volume regulation in yeasts. 


\section{METHODS}

Organisms, media and growth conditions. Saccharomyces cerevisiae (X2180-1B; Yeast Genetic Stock Center, Berkeley, Calif., USA), was maintained at $25^{\circ} \mathrm{C}$ on MYGP agar, of composition ( $\mathrm{g} \mathrm{l}^{-1}$ ): malt extract (Lab M) 3; yeast extract (Difco), 3; bacteriological peptone (Oxoid), 5; D-glucose, 10; agar (Lab M, no. 2), 15. The liquid basal medium (BM) had the following composition ( $\mathrm{g} \mathrm{l}^{-1}$ ): D-glucose, $20 \cdot 0 ; \mathrm{KH}_{2} \mathrm{PO}_{4}, 2 \cdot 72 ; \mathrm{K}_{2} \mathrm{HPO}_{4} .3 \mathrm{H}_{2} \mathrm{O}, 5 \cdot 22$; $\left(\mathrm{NH}_{4}\right)_{2} \mathrm{SO}_{4}, 2 \cdot 0 ; \mathrm{MgSO}_{4} .7 \mathrm{H}_{2} \mathrm{O}, 0 \cdot 12 ; \mathrm{FeSO}_{4} .7 \mathrm{H}_{2} \mathrm{O}, 0.0022 ; \mathrm{ZnSO}_{4} .7 \mathrm{H}_{2} \mathrm{O}, 0.004 ; \mathrm{MnSO}_{4} .4 \mathrm{H}_{2} \mathrm{O}, 0.004 ;$ $\mathrm{CuSO}_{4} \cdot 5 \mathrm{H}_{2} \mathrm{O}, 0 \cdot 0004$; yeast extract (Difco), $1 \cdot 0$.

Starter cultures were prepared by loop-inoculating $100 \mathrm{ml}$ of culture medium (BM) with cells from an MYGP agar plate and incubating for $18 \mathrm{~h}$ at $25^{\circ} \mathrm{C}$ on an orbital shaker $\left(100\right.$ cycles $\left.\mathrm{min}^{-1}\right)$. Exponentially growing starter cultures were used, after one further subculture $(12 \mathrm{~h})$, to inoculate experimental flasks. These were incubated as above and contained $100 \mathrm{ml}$ or $250 \mathrm{ml}$ of basal medium (BM; total osmotic pressure $0.72 \mathrm{MPa}$ ) or with added $\mathrm{NaCl}$ at $2.28 \%(\mathrm{w} / \mathrm{v})(\mathrm{BM}+0.39 \mathrm{M}-\mathrm{NaCl}$; total osmotic pressure $2.48 \mathrm{MPa})$ or $\mathrm{D}$-sorbitol at $12 \%(\mathrm{w} / \mathrm{v})$ $(\mathrm{BM}+0.66 \mathrm{M}$-sorbitol; total osmotic pressure $2.48 \mathrm{MPa})$.

The osmotic pressures of experimental solutions were calculated from published tables (Wolf et al., 1979) and confirmed during experimental procedures using a cryoscopic osmometer (Osmomat 030, Gonotec).

Determination of cell number, cell volume and non-osmotic volume. Whole cells, and protoplasts, were counted and sized using a Coulter ZB(I) counter and C1000 Channelyzer linked to an Acorn microcomputer to facilitate estimation of mean cell volume (Reed et al., 1985). A $50 \mu \mathrm{m}$ aperture (path length, $60 \mu \mathrm{m}$ ) was used throughout. To prevent volume changes during analysis, cells were counted and sized in an iso-osmotic $\mathrm{NaCl}$ solution and the osmotic pressure was the same on both sides of the aperture tube (Reed et al., 1987).

For each value of mean cell volume, three to five replicates were used, with $15000-20000$ cells per $0.05 \mathrm{ml}$ sample. Instrument settings were $[\mathrm{ZB}(\mathrm{I})$ unit]: 1 /amplification $=2,1$ /aperture current $=0.354$, lower threshold $=5$, volume constant $\left(K_{v}\right)=2 \cdot 2$ (matching switch, 5k). Size distributions were obtained using the C1000 Channelyzer unit, at a base channel threshold of 5 and a window width of 100 . These adjustments typically gave a unimodal $(100 \%)$ volume peak for cells of $S$. cerevisiae in channel $29-32$, decreasing to $<1 \%$ at the upper and lower Channelyzer settings. The Channelyzer display thus encompassed a wide enough range of volume (21-fold, between base channel threshold and upper setting) to include newly formed cells and mature cells with buds.

To calculate the cell turgor pressure $\left(P_{\text {cell }}\right)$, volumetric elastic modulus ( $\varepsilon$ ) and the non-osmotic volume (NOV) of whole cells, the Boyle-van't Hoff relationship was used. Cells were suspended in $\mathrm{NaCl}$ solutions, with osmotic pressures ranging from 0.72-9.92 $\mathrm{MPa}$, for 1-2 min at room temperature to allow for shrinkage (Morris et al., 1986) and volumes were then measured. The cell volume was then plotted against the reciprocal of the corresponding external osmotic pressure. For protoplast volume analysis the first external osmotic pressure used was iso-osmotic with that of the medium in which the protoplasts were made (4.36 MPa). Dilutions of the protoplast suspension were made by dropwise addition of distilled water and, at appropriate dilutions, a $0 \cdot 1 \mathrm{ml}$ sample was transferred to $25 \mathrm{ml}$ of iso-osmotic $\mathrm{NaCl}$ for $1 \mathrm{~min}$ at $25^{\circ} \mathrm{C}$. The protoplast volume was then measured in this solution. After each volume analysis $1 \mathrm{ml}$ of this diluted protoplast suspension was spun down $(1300 \mathrm{~g}, 30 \mathrm{~s})$ and the osmotic pressure of the supernate measured using a cryoscopic osmometer.

Analysis of low molecular mass carbohydrates. Samples of approximately $5 \times 10^{7}$ cells were filtered onto glassfibre filter discs of $25 \mathrm{~mm}$ diameter (type GF/C, Whatman) or a similar number of protoplasts were sampled by low-speed centrifugation $(250 \mathrm{~g}, 5 \mathrm{~min}$ ). In both cases, samples were washed three times with $10 \mathrm{ml}$ iso-osmotic $\mathrm{NaCl}$ solution to remove extracellular carbohydrates, without administering a hypo-osmotic shock (see Wethered et al., 1985) and then immediately extracted in $80 \%(\mathrm{v} / \mathrm{v})$ aqueous ethanol using $0.6 \mathrm{mg}$ erythritol as an internal standard for monosaccharides/polyols and $0.6 \mathrm{mg}$ sucrose as an internal standard for disaccharides. After overnight extraction, ethanol was evaporated off and the samples were desiccated for at least $24 \mathrm{~h}$ prior to gasliquid chromatography using trimethylsilyl-derivatized samples extracted in pyridine (Reed et al, , 1984b). A glass column $(2 \mathrm{~m} \times 4 \mathrm{~mm})$ of Chromosorb W (Phase Separations) coated with a stationary phase of $4 \%$ SE52 methylphenyl silicone gum (Pye Unicam) was fitted to a Varian 3700 gas-liquid chromatograph with flame ionization detection. A temperature programme from $140-280^{\circ} \mathrm{C}$ at $20^{\circ} \mathrm{C} \mathrm{min}^{-1}$, holding the initial temperature constant for $1 \mathrm{~min}$ and the final temperature constant for $6 \mathrm{~min}$ was used. Carbohydrates were identified and peak areas quantified using a Hewlett Packard HP3390A integrator.

Isolation of yeast protoplasts. Exponentially growing cells were harvested by centrifugation $(1200 \mathrm{~g}, 5 \mathrm{~min})$,

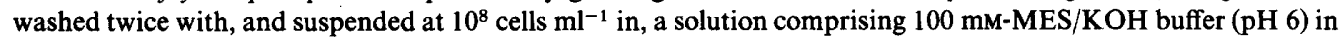
$21.8 \%(\mathrm{w} / \mathrm{v})(1.2 \mathrm{M})$ sorbitol (PM) giving an osmotic pressure of $4.36 \mathrm{MPa}$. Novozym 234 (Novo Enzymes) was added at $10 \mathrm{mg} \mathrm{m}^{-1}\left(\mathrm{PM}+\right.$ Novozym) and the suspension incubated at $25^{\circ} \mathrm{C}$ with stirring for $1 \mathrm{~h}$ (White \& Gadd, 1987). This method was shown to be $\geqslant 99 \%$ efficient by counting with a haemocytometer the number of cells remaining after a 1 in 10 dilution with distilled water and comparing this to the number of cells/protoplasts after a 1 in 10 dilution with PM. Protoplasts were then harvested by low-speed centrifugation $(250 \mathrm{~g}, 5 \mathrm{~min})$, washed once with, and stored in, $20 \mathrm{mM}-\mathrm{MES} / \mathrm{KOH}$ buffer (pH 6) in $21.8 \%$ sorbitol at $4{ }^{\circ} \mathrm{C}$ for no longer than $4 \mathrm{~h}$. 
A medium of similar osmotic pressure, but with added glucose (GPM) and mineral salts at BM concentrations was also used and the sorbitol level in this medium was reduced to $18.5 \%(\mathrm{w} / \mathrm{v})(0.85 \mathrm{M})$, giving an osmotic pressure of 4.20 MPa.

Glycerol production by protoplasts. Protoplasts were prepared in PM + Novozym (1 h) and then incubated at $25^{\circ} \mathrm{C}$ either in PM (pH 6) or in GPM ( $\mathrm{pH} \mathrm{6)}$ ), the latter having glucose as a carbon source. As a control, whole cells were also incubated in the above media with the omission of Novozym 234 (i.e. PM and GPM). Protoplast samples $\left(3 \times 10^{7}-10^{8}\right)$ were harvested by low-speed centrifugation $(250 \mathrm{~g}, 5 \mathrm{~min})$ and analysed for low molecular mass carbohydrates as described above. Microscopic examinations were made of the protoplasts to check morphology and osmotic sensitivity throughout the time-course.

\section{RESULTS}

\section{Osmotically induced volume changes in whole cells and protoplasts}

The relationship between volume and external osmotic pressure for whole cells and protoplasts of $S$. cerevisiae is shown in Fig. 1. With increasing external osmotic pressure whole cells did not behave as ideal osmometers until their cell turgor pressure had been dissipated at an external osmotic pressure of 2.48 MPa. At osmotic pressures above this value the cells showed osmometric behaviour, with a linear relationship between volume and the reciprocal of the external osmotic pressure. Protoplasts, lacking a cell wall, had no appreciable turgor pressure and showed osmometric behaviour over a wider range of external osmotic pressures. With increasing dilution, protoplast lysis was observed microscopically at an external osmotic pressure of approximately $1.29 \mathrm{MPa}$, presumably due to excessive volume increase caused by the inflow of water from the dilute medium. At lower osmolalities the protoplast volume decreased substantially, reaching $25 \mathrm{fl}$ at $0.92 \mathrm{MPa}$ (Fig. 1). Further reductions in external osmolality caused extensive lysis and satisfactory volume distributions could not be obtained using the Channelyzer.

The Boyle-van't Hoff plots (Fig. 1) can be used to derive the non-osmotic volume (NOV), internal osmotic pressure $\left(\pi_{\mathrm{i}}\right)$, and cell turgor pressure $\left(P_{\text {cell }}\right)$ at any given external osmotic pressure $\left(\pi_{\mathrm{e}}\right)$ and the volumetric elastic modulus $(\varepsilon)$. Linear regression analysis (correlation coefficient $\geqslant 0.970$ in all cases) was used to calculate the NOV of both cell types as the intercept of the $y$-axis. Whole cells had a NOV of $48 \%$ of their initial volume in basal medium (BM); protoplasts had a NOV of $35 \%$ of the original protoplast volume in $1.2 \mathrm{M}$-sorbitol, pH 6.0 (PM).

Calculation of the internal osmotic pressure of cells at any given $\pi_{\mathrm{e}}$ uses the relationship $P_{\text {cell }}=\pi_{\mathrm{i}}-\pi_{\mathrm{e}}$ (Dainty, 1976). Therefore, when $P_{\text {cell }}=0$, at high $\pi_{\mathrm{e}}, \pi_{\mathrm{i}}=\pi_{\mathrm{e}}$. Having thus calculated a value for $\pi_{\mathrm{j}}$, at a volume where $P_{\text {cell }}=0$, the Boyle-van't Hoff relationship ( $\pi V=$ constant) can then be applied, where $V=$ the osmotically active volume, to calculate $\pi_{\mathrm{i}}$ where the cell has positive turgor pressure. Thus $P_{\text {cell }}$ can be calculated for all points on the Boyle-van't Hoff plot. Finally, $\varepsilon$ can be calculated as

$$
\Delta P_{\text {cell }}=\varepsilon \frac{\Delta V}{V_{\mathrm{r}}}
$$

where $V$ is the total cell volume and $V_{\mathrm{r}}$ is a reference volume, usually the cell volume where $P_{\text {cell }}=0$ (see Dainty, 1976).

Tables 1 and 2 give values for cell volume, $P_{\text {cell }}$ and $\pi_{\mathrm{i}}$, at given external osmotic pressures, for mid-exponential phase $(1 \mathrm{~h})$ and stationary phase $(5 \mathrm{~d})$ yeast cells respectively. In stationary phase cells in basal medium $\left(\pi_{\mathrm{e}}=0.72 \mathrm{MPa}\right)$, with no requirement for positive turgor for growth, the turgor pressure was lower than in mid-exponential phase cells. Stationary phase cells also had a lower mean elastic modulus of $1.95 \mathrm{MPa}$, compared to mid-exponential cells (3.25 MPa). These values for $\varepsilon$ were calculated over the range of $\pi_{\mathrm{e}}$ where $P_{\text {cell }}>0$. In both cases as $\pi_{\mathrm{e}}$ increased, cell volume and $P_{\text {cell }}$ decreased while $\pi_{\mathrm{i}}$ increased, until, at an $\pi_{\mathrm{e}}$ of $2.48 \mathrm{MPa}, P_{\text {cell }}$ was dissipated and $\pi_{\mathrm{i}}=\pi_{\mathrm{e}}$.

The volumes of whole cells and protoplasts in a hyperosmotic medium, with and without added glucose (i.e. PM and GPM respectively), were monitored using the Coulter counter over $12 \mathrm{~h}$. In all cases, the volumes after $1 \mathrm{~h}$ in a hyperosmotic medium were lower than the original 


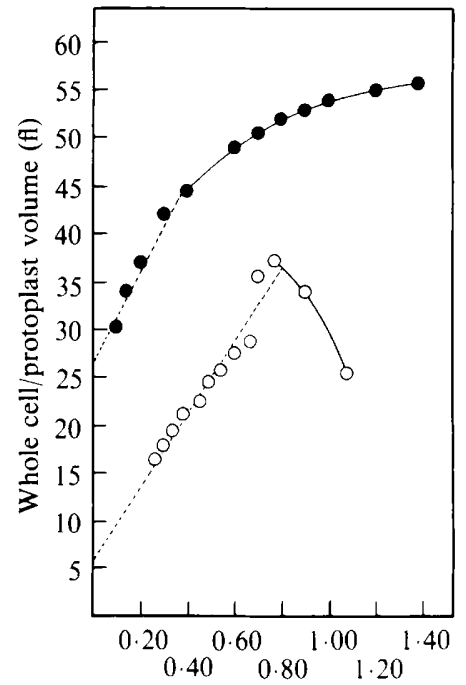

$1 /$ External osmotic pressure $\left(\mathrm{MPa}^{-1}\right)$

Fig. 1

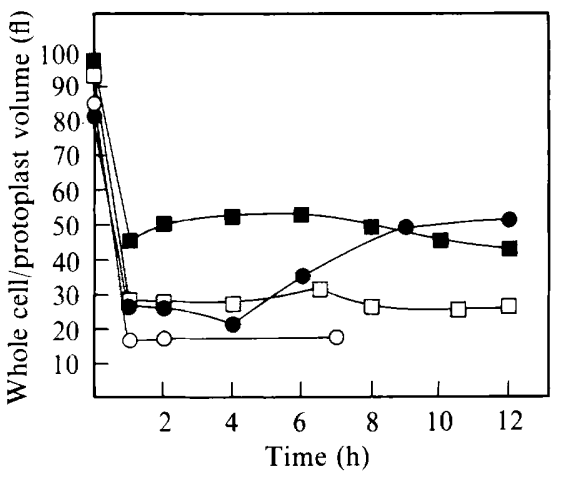

Fig. 2

Fig. 1. Boyle-van't Hoff plots for whole cells $(O)$ and protoplasts $(O)$ of $S$. cerevisiae. Mean values from three replicate determinations are shown; SD $<1 \mathrm{fl}$.

Fig. 2. Volume changes of $S$. cerevisiae whole cells $(\square, \square)$ and protoplasts $(O, O)$ during incubation in GPM (closed symbols) or PM (open symbols). Mean values from three replicate determinations are shown; SD $<1$ fl.

Table 1. Changes in cell volume, turgor pressure $\left(P_{\text {cell }}\right)$ and internal osmotic pressure $\left(\pi_{i}\right)$ in relation to external osmotic pressure $\left(\pi_{e}\right)$ for mid-exponential phase cells of $S$. cerevisiae grown in $B M$

The NOV was $48 \%$ and the elastic modulus $(\varepsilon)$ was $3.25 \mathrm{MPa}$.

$\begin{array}{cccc}\begin{array}{c}\pi_{\mathrm{e}} \\ (\mathrm{MPa})\end{array} & \begin{array}{c}\text { Total } \\ \text { cell volume } \\ \text { (f) }\end{array} & \begin{array}{c}P_{\text {cell }} \\ (\mathrm{MPa})\end{array} & \begin{array}{c}\pi_{\mathrm{i}} \\ (\mathrm{MPa})\end{array} \\ 0.72 & 55.7 & 0.81 & 1.53 \\ 0.83 & 54.9 & 0.75 & 1.58 \\ 0.99 & 54.1 & 0.63 & 1.62 \\ 1.10 & 52.9 & 0.59 & 1.69 \\ 1.24 & 52.1 & 0.51 & 1.75 \\ 1.42 & 50.8 & 0.43 & 1.84 \\ 1.65 & 49.1 & 0.33 & 1.98 \\ 2.48 & 44.6 & 0 & 2.48\end{array}$

Table 2. Changes in cell volume, turgor pressure $\left(P_{\text {cell }}\right)$ and internal osmotic pressure $\left(\pi_{i}\right)$ in relation to external osmotic pressure $\left(\pi_{e}\right)$ for stationary phase cells of $S$. cerevisiae grown in $B M$

The NOV was $49 \%$ and the elastic modulus ( $\varepsilon$ ) was $1.95 \mathrm{MPa}$.

Total

$\begin{array}{cccc}\begin{array}{c}\pi_{\mathrm{e}} \\ (\mathrm{MPa})\end{array} & \begin{array}{c}\text { cell volume } \\ \text { (f) }\end{array} & \begin{array}{c}P_{\text {cell }} \\ (\mathrm{MPa})\end{array} & \begin{array}{c}\pi_{\mathrm{i}} \\ (\mathrm{MPa})\end{array} \\ 0.72 & 44.5 & 0.61 & 1.33 \\ 0.83 & 43.2 & 0.58 & 1.41 \\ 0.99 & 42.0 & 0.50 & 1.49 \\ 1.10 & 41.0 & 0.47 & 1.57 \\ 1.24 & 39.8 & 0.43 & 1.67 \\ 1.42 & 39.2 & 0.31 & 1.73 \\ 1.65 & 37.4 & 0.27 & 1.93 \\ 2.48 & 33.9 & 0 & 2.48\end{array}$




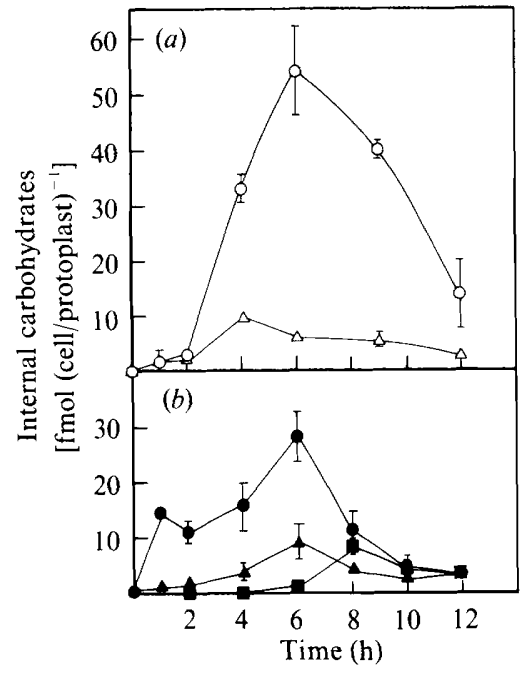

Fig. 3

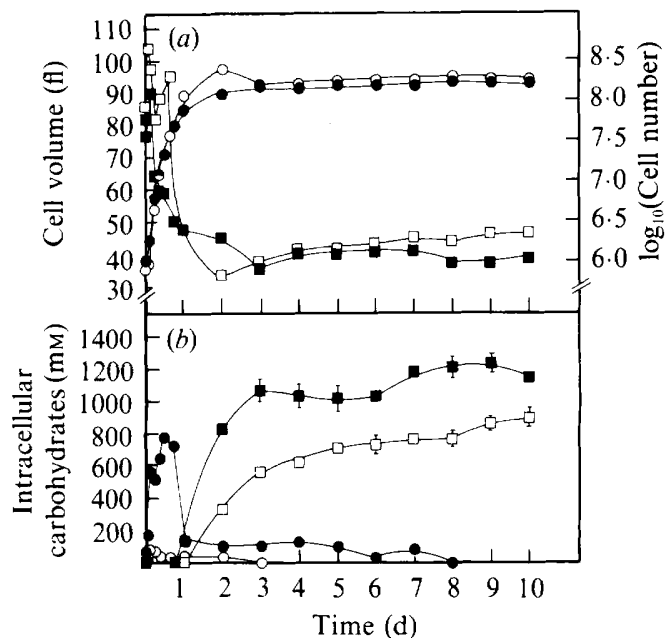

Fig. 4

Fig. 3. Synthesis of internal carbohydrates by protoplasts $(a)$ and whole cells $(b)$ of $S$. cerevisiae during incubation in GPM. $\bigcirc, \bigcirc$, Glycerol; $\boldsymbol{\square}$, trehalose; $\Delta, \Delta$, sorbitol. Mean values from three replicate determinations \pm SD shown where significant.

Fig. 4. Growth, changes in cell volume and synthesis of internal carbohydrates by $S$. cerevisiae grown in the absence or presence of salt. Open symbols, $\mathrm{BM}$; closed symbols, $\mathrm{BM}+\mathrm{NaCl}$. $(a) \bigcirc, \bigcirc, \log _{10}$ cell numbers; $\square, \mathbf{\square}$, cell volume. $(b) \bigcirc, 0$, Glycerol; $\square, \boldsymbol{\square}$, trehalose. Mean values from three replicate determinations \pm SD shown where significant.

values. Without glucose, neither whole cells nor protoplasts increased their volume; protoplasts in a medium with no added glucose lysed after $7 \mathrm{~h}$ (Fig. 2). However, the volumes of protoplasts and cells were higher after $1 \mathrm{~h}$ in the medium with added glucose. Furthermore, whole cells showed a small increase in volume after $1 \mathrm{~h}$, and protoplasts showed a sustained increase in volume after $4 \mathrm{~h}$. After $21.5 \mathrm{~h}$ in GPM the protoplasts remained intact, and were still osmotically sensitive and thus had not regenerated a cell wall. These protoplasts were substantially larger $(166 \mathrm{fl})$ than at $12 \mathrm{~h}$ and microscopic examination showed that they had large vacuoles which occupied most of their volume.

\section{Glycerol production by protoplasts and whole cells}

When incubated in PM neither protoplasts nor whole cells synthesized glycerol, nor any other low molecular mass carbohydrate. Fig. $3(a, b)$ shows the accumulation of carbohydrates by protoplasts and whole cells respectively, when incubated in GPM. Maximum internal glycerol levels were reached in protoplasts and whole cells after $6 \mathrm{~h}$ in GPM, after which they decreased. Protoplasts appeared to produce more glycerol than whole cells. Low levels of sorbitol were detected within protoplasts and cells, presumably due to uptake from the medium. Maximum sorbitol levels were reached after $4 \mathrm{~h}$ in protoplasts and $6 \mathrm{~h}$ in cells; these levels did not exceed $10 \mathrm{fmol}$ (cell/protoplast) ${ }^{-1}$ and did not contribute to the overall internal osmotic pressure to the same extent as glycerol. Protoplasts did not synthesize trehalose during this experiment, whereas whole cells showed trehalose synthesis in GPM after $6 \mathrm{~h}$.

\section{Effect of different osmotica on glycerol production by whole cells}

$S$. cerevisiae cells were inoculated from BM into BM $+\mathrm{NaCl}$. Fig. 4(a) shows the growth and cell volumes of these cells and of control cells inoculated into fresh basal medium; Fig. $4(b)$ shows the corresponding intracellular glycerol and trehalose levels. In Figs 4-6 the carbohydrate concentrations are expressed in terms of the osmotically active volume of the cells. Growth was only marginally reduced in $\mathrm{BM}+\mathrm{NaCl}$; in $\mathrm{BM}$ the doubling time was $2.0 \mathrm{~h}$ and in $\mathrm{BM}+\mathrm{NaCl}$ 


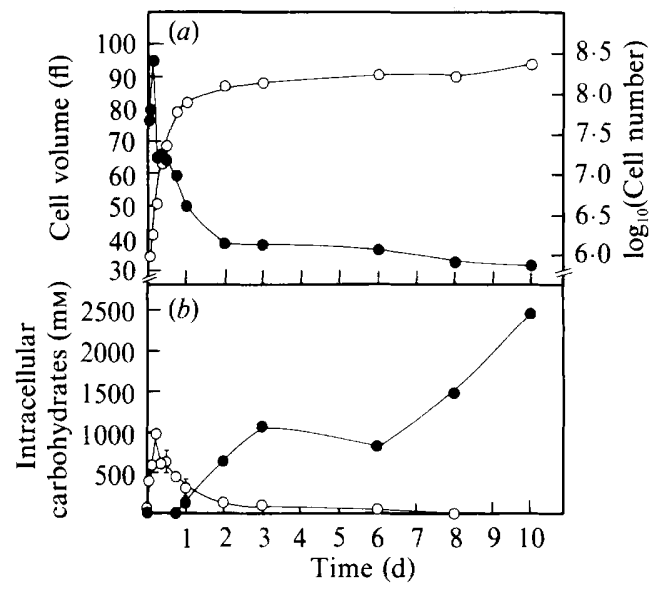

Fig. 5

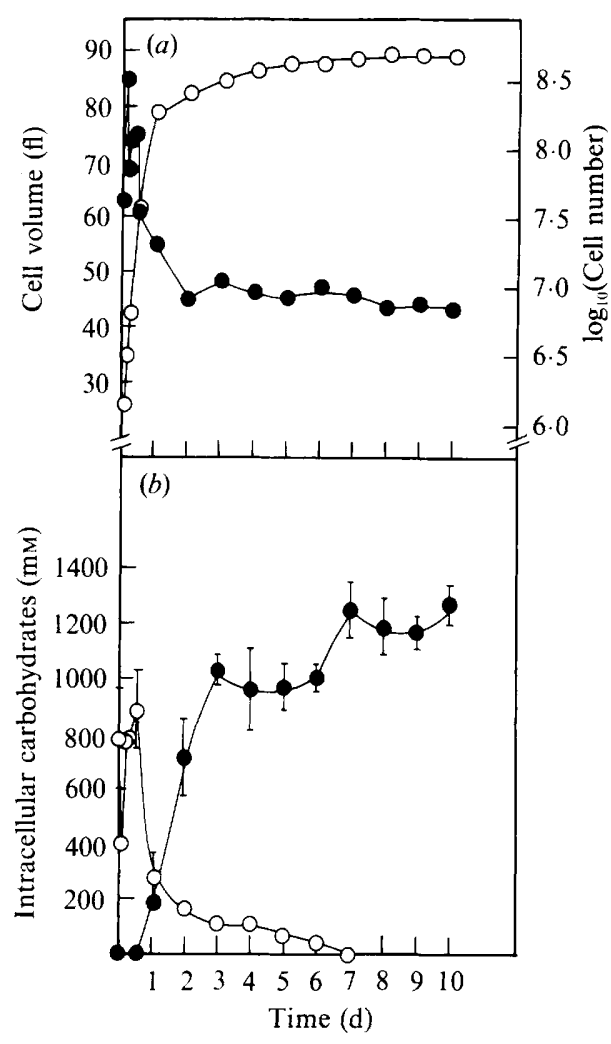

Fig. 6

Fig. 5. Growth, changes in cell volume and synthesis of internal carbohydrates by $S$. cerevisiae transferred from BM to BM + sorbitol. $(a), \bigcirc, \log _{10}$ cell number; $O$, cell volume. $(b) \bigcirc$, Glycerol; $\boldsymbol{O}$, trehalose. Mean values from three replicate determinations \pm SD shown where significant.

Fig. 6. Growth, changes in cell volume and synthesis of internal carbohydrates by $S$. cerevisiae transferred from $\mathrm{BM}+\mathrm{NaCl}$ to fresh $\mathrm{BM}+\mathrm{NaCl} .(a) \bigcirc, \log _{10}$ cell number;, cell volume. $(b) \bigcirc$, Glycerol; , trehalose. Mean values from three replicate determinations \pm SD shown where significant.

the doubling time was $2 \cdot 3 \mathrm{~h}$. However, the addition of $2 \cdot 28 \%(\mathrm{w} / \mathrm{v}) \mathrm{NaCl}$ would have increased the osmotic pressure of the medium from $0.72 \mathrm{MPa}$ to $2.48 \mathrm{MPa}$ which would have dissipated cell turgor (Table 1). Thus the cells must have restored turgor, presumably by glycerol synthesis, before expansion growth could occur. The volume of these cells increased between 1 and $3 \mathrm{~h}$ after inoculation (the initial osmotically induced shrinkage, shown in Fig. 1, is not represented on this graph), and subsequently decreased during mid-exponential phase. In control cells a similar sequence occurred, although the cell volume generally remained higher during the exponential phase, declining in the stationary phase. Fig. 4(b) shows that glycerol was synthesized rapidly by exponentially growing cells in $\mathrm{BM}+\mathrm{NaCl}$ and decreased at the end of exponential growth. Control cells transferred to BM did not synthesize significant amounts of glycerol. Cells grown in $\mathrm{BM}+\mathrm{NaCl}$ showed synthesis of trehalose by $1 \mathrm{~d}$, reaching a higher intracellular level than control cells in BM, which showed no trehalose synthesis until $2 \mathrm{~d}$.

The results obtained when cells of $S$. cerevisiae were inoculated into medium with an osmotic pressure elevated to 2.48 MPa with D-sorbitol (BM + sorbitol) are shown in Fig. 5(a,b). The doubling time for these cells was $1.9 \mathrm{~h}$, as compared to $2.0 \mathrm{~h}$ in BM (in Fig. $4 a$ ). Cell volume was increased at $1 \mathrm{~h}$ and $3 \mathrm{~h}$ after inoculation and then decreased, as in $\mathrm{NaCl}$. Glycerol was synthesized to a level somewhat higher than that of $\mathrm{NaCl}$-treated cells (Fig. $4 b$ ). However, synthesis was more rapid and the maximum internal concentration was reached after $6 \mathrm{~h}$ in $\mathrm{BM}+$ sorbitol (Fig. $5 b$ ) as compared to $12 \mathrm{~h}$ in $\mathrm{NaCl}$ (Fig. $4 b$ ). The glycerol level then dropped, 
although not as rapidly as in $\mathrm{NaCl}$, since low levels of glycerol were still detectable at $6 \mathrm{~d}$. Trehalose synthesis was observed at $1 \mathrm{~d}$ with higher levels for sorbitol-treated cells than those for control cells, particularly towards the end of the experiment.

When exponential phase cells, grown for two previous subcultures in $\mathrm{BM}+\mathrm{NaCl}$, were transferred to fresh medium of identical composition, a doubling time of $2.6 \mathrm{~h}$ was observed (Fig. 6a). Cell volume changed over the first $12 \mathrm{~h}$, in a similar manner to control cells (Fig. 4a), and then decreased at the start of stationary phase. Since the cells were transferred from $\mathrm{BM}+\mathrm{NaCl}$, the initial intracellular glycerol concentration was high. However, transfer to fresh, iso-osmotic $\mathrm{BM}+\mathrm{NaCl}$ medium resulted in a marked decrease in the internal glycerol level at $1 \mathrm{~h}$ which then rapidly recovered and was maintained until the end of exponential growth. Intracellular glycerol then decreased and was undetectable by $7 \mathrm{~d}$. Intracellular trehalose was observed at $24 \mathrm{~h}$ and increased during stationary phase to levels higher than those reached by control cells in BM (Fig. $4 b$ ).

\section{DISCUSSION}

From the Boyle-van't Hoff plots (Fig. 1) it is clear that whole cells maintained a positive turgor pressure when transferred to $\mathrm{NaCl}$ solutions of elevated osmotic pressure up to 2.48 $\mathrm{MPa}$; at this point cell turgor became zero and the cells behaved as osmometers. Arnold \& Lacy (1977) calculated that incipient plasmolysis $\left(P_{\text {cell }}=0\right)$ occurred in $S$. cerevisiae at a similar osmotic pressure of $2.85 \mathrm{MPa}$, from changes in the Ficoll-accessible space of the cells with increasing external osmotic pressure. In contrast, protoplasts showed osmometric behaviour over a wider range of osmotic pressures, since they were not able to generate a significant turgor pressure.

Whole cells had a larger NOV than protoplasts in proportional and absolute terms (Fig. 1), suggesting that some of this NOV may consist of cell wall material. The exact nature of the remaining component of the NOV is not known; however, organelles and storage granules may also contribute. Reed et al. (1987) calculated a NOV of $34 \%$ for $S$. cerevisiae cells using the data of Arnold \& Lacy (1977), in accordance with a value of $35 \%$ calculated for late-exponential phase cells by Morris et al. (1986). The values for NOV of mid-exponential and stationary phase cells shown in Tables 1 and 2 are somewhat higher. The work by Morris et al. (1986) used video microscopy to reveal that shrinkage occurred within the first minute of exposure to a hyperosmotic solution of $\mathrm{NaCl}$ at $20^{\circ} \mathrm{C}$, and that the cell volume then remained stable for up to $5 \mathrm{~min}$. The changes in linear dimensions of cells of $S$. cerevisiae during shrinkage were not isotropic; this increases the difficulties involved in volume calculations from this technique. Such non-isotropic shrinkage does not significantly affect volume analysis using the Coulter counter.

When whole cells were transferred to media of increasing osmotic pressure there was a movement of water from the cells to the medium and hence a decrease in volume (Tables 1 and 2). While the internal osmotic pressure was higher than the external osmotic pressure, a positive turgor pressure $\left(P_{\text {cell }}\right)$ was maintained. In agreement with Morris et al. (1986) plasmolysis was not observed in whole cells in extreme hyperosmotic media, when examined by light microscopy; it is likely that the yeast cell wall shrinks with the protoplast when the cell turgor pressure has been dissipated by elevated external osmotic pressure (i.e. $>2.48 \mathrm{MPa}$ ). In BM the internal osmotic pressure of exponentially growing whole cells was $1.53 \mathrm{MPa}$ (Table 1) which agrees with the value of $1.34 \mathrm{MPa}$ obtained by Levin et al. (1979) and $1.20 \mathrm{MPa}$, calculated from the data of Arnold \& Lacy (1977) for yeast cells in distilled water; these cells are likely to have a lower $\pi_{\mathrm{i}}$ due to the leakage of certain internal solutes from the cells in distilled water (Wethered et al., 1985). While the values of Levin et al. (1979) and Arnold \& Lacy (1977) will also be equivalent to the cell turgor pressure, since $\pi_{\mathrm{e}}=0$, the turgor pressure obtained during the present study for exponentially growing cells in $\mathrm{BM}\left(\pi_{\mathrm{e}}=0.72 \mathrm{MPa}\right)$ was $0.81 \mathrm{MPa}$ (Table 1$)$, a lower value than for yeast cells in distilled water. However, an increase in the turgidity of cells would be expected when suspended in distilled water. In BM, stationary phase cells had a lower $P_{\text {cell }}$ of $0.61 \mathrm{MPa}$. This is expected as stationary phase cells no longer require a critical $P_{\text {cell }}$ to drive cell expansion. Cells growing exponentially in $\mathrm{BM}$ had an $\varepsilon$ of $3.25 \mathrm{MPa}$; a similar range of 
values for $\varepsilon(2.5-3.0 \mathrm{MPa})$ has been calculated from a Boyle-van't Hoff plot of the data of Arnold \& Lacy (1977). Levin et al. (1979) derived a somewhat higher value for $\varepsilon$ of $4.7 \mathrm{MPa}$ from the data of Conway \& Armstrong (1961), indicating a less elastic cell wall than suggested by our data. Differences in strain history, media and the techniques used undoubtedly account for some of the variation in $\varepsilon$. The elastic modulus varied with culture age, with a higher value during exponential growth and decreasing in stationary phase. This is likely to be related to the lower turgor of stationary phase cells, and to changes in cell wall composition with age.

Yeast protoplasts are normally stored at $4{ }^{\circ} \mathrm{C}$ to inhibit metabolic activity which can lead to lysis (Indge, 1968). However, protoplasts can regenerate cell walls under suitable conditions and recommence growth (Nečas, 1979). Kotyk et al. (1985) compared the transport properties of $S$. cerevisiae protoplasts with intact cells and found that constitutive monosaccharide transport (e.g. D-xylose), as well as the inducible transport of D-galactose, were unaltered in protoplasts. They also showed that the utilization of glucose was not depressed, but protoplast protontranslocating capacity was impaired. The present study examined specific aspects of protoplast metabolism with respect to the high osmotic pressure of the medium necessary to compensate for cell wall removal (i.e. 4.20-4.36 MPa). Both whole cells and protoplasts produced glycerol internally in this medium if supplied with glucose. When glycerol was synthesized there was a concurrent increase in protoplast volume (Figs 2 and 3); no volume increase was seen in protoplasts incubated in the absence of glucose. Although protoplast glycerol levels decreased after $6 \mathrm{~h}$ (Fig. $3 a$ ) and thus appeared to be controlled by processes other than turgor regulation, protoplast volume did not show a similar change. After $21.5 \mathrm{~h}$ protoplasts incubated with glucose increased their volume, contained large vacuoles and remained osmotically fragile. These results indicate that $S$. cerevisiae protoplasts were able to accumulate osmotica in the presence of glucose and thus increase their volume. The decrease in intracellular glycerol after $6 \mathrm{~h}$ may be due to changes in glycerol metabolism, or the leakage of intracellular glycerol into the medium. In either case, other solutes must be involved in generating $\pi_{\mathrm{i}}$ after $6 \mathrm{~h}$; these may include sorbitol (Fig. 3) and/or inorganic ions from the external medium. These results contrast with the observations of Clint (1985) on Commelina communis guard cell protoplasts, which regulated their volume within narrow limits over a range of external osmotic pressures if incubated for several hours in the presence of added external $\mathrm{KCl}$. It is also interesting to note that under these conditions whole cells of $S$. cerevisiae began to produce trehalose after $6 \mathrm{~h}$ in GPM; no trehalose synthesis was seen in protoplasts up to $12 \mathrm{~h}$ (Fig. 3). That whole cells began to produce trehalose after $6 \mathrm{~h}$ in GPM $\left(\pi_{\mathrm{e}}=4.36 \mathrm{MPa}\right)$ indicates that increased osmotic stress may lead to early trehalose synthesis since trehalose was synthesized after $24 \mathrm{~h}$ by cells in $\mathrm{BM}+\mathrm{NaCl}\left(\pi_{\mathrm{e}}=2.48 \mathrm{MPa}\right.$; Figs $4 b$ and $\left.6 b\right)$ and by cells in $\mathrm{BM}+\operatorname{sorbitol}\left(\pi_{\mathrm{e}}=2.48 \mathrm{MPa}\right.$; Fig. $5 b)$ as compared to $48 \mathrm{~h}$ by cells in basal medium $\left(\pi_{\mathrm{e}}=0.72 \mathrm{MPa}\right.$; Fig. $\left.4 b\right)$. In addition to this early synthesis trehalose reached a higher maximum level in cells grown in media with elevated osmotic pressure. This was most apparent in BM + sorbitol, although it is possible that the cells were able to utilize sorbitol to synthesize trehalose (see Quain \& Bolton, 1987). The accumulation of trehalose may be associated with periods of reduced growth rate, and in $S$. cerevisiae only when glucose is exhausted are cells able to accumulate trehalose in significant amounts (see Panek, 1985; Gadd, 1988). Trehalose is known to have protective properties in desiccated cells (Panek, 1985; Gadd et al., 1987) and has been reported as an osmolyte in cyanobacteria (Reed et al., 1984b) and E. coli (Larsen et al., 1987).

In whole cells, zero turgor pressure was reached on transfer to a solution with an osmotic pressure of $2.48 \mathrm{MPa}$ (Fig. 1). When transferred to $\mathrm{BM}+\mathrm{NaCl}$ at this osmotic pressure whole cells of $S$. cerevisiae synthesized glycerol as their compatible organic solute. Brown et al. (1986) published data for glycerol accumulation in $S$. cerevisiae transferred to $8 \%(\mathrm{w} / \mathrm{v}) \mathrm{NaCl}$ $\left(\pi_{\mathrm{e}}=6.8 \mathrm{MPa}\right)$ showing that the osmotically induced response did not begin until $6 \mathrm{~h}$ after initial exposure and was preceded by a transient, smaller initial increase in glycerol. Our data show that glycerol was accumulated after $1 \mathrm{~h}$ in $\mathrm{NaCl}$-containing medium and continued until the end of the exponential phase (Fig. 4b). However, Brown et al. (1986) used a synthetic medium containing $0.5 \%(\mathrm{w} / \mathrm{v})$ glucose whereas $\mathrm{BM}+\mathrm{NaCl}$ contained $2 \%(\mathrm{w} / \mathrm{v})$ glucose. Also $\mathrm{BM}+\mathrm{NaCl}$ had a lower external osmotic pressure of $2.48 \mathrm{MPa}$. André et al. (1988) have 
demonstrated that increased levels of external $\mathrm{NaCl}$ lead to an increased lag phase prior to osmotically induced glycerol production in Debaryomyces hansenii; a similar phenomenon may occur in S. cerevisiae, accounting for the delay in glycerol synthesis observed by Brown et al. (1986).

Yagi (1988) has suggested that in Zygosaccharomyces rouxii a definite intracellular level of glycerol is required prior to initiation of growth in cells stressed using $\mathrm{NaCl}, \mathrm{KCl}$ or $\mathrm{MgCl}_{2}$. This was not observed with $S$. cerevisiae (Fig. $4 a$ ), since transfer of these cells to $\mathrm{BM}+\mathrm{NaCl}$ with an osmotic pressure of $2.48 \mathrm{MPa}$ did not cause a significant lag in growth. Fig. $4(a, b)$ shows that when whole cells were transferred from $\mathrm{BM}$ to $\mathrm{BM}+\mathrm{NaCl}$ glycerol production began within $1 \mathrm{~h}$, with an increase in cell number at $3 \mathrm{~h}$. However, the cells continued to accumulate glycerol during growth with a maximum internal concentration of approximately $780 \mathrm{~mm}$ at $12 \mathrm{~h}$. Data obtained from a Boyle-van't Hoff plot of $S$. cerevisiae $12 \mathrm{~h}$ after inoculation from BM intc $\mathrm{BM}+\mathrm{NaCl}\left(\pi_{\mathrm{e}}=2.48 \mathrm{MPa}\right)$ gave a $\pi_{\mathrm{i}}$ of $3.11 \mathrm{MPa}$ and a NOV of $47 \%$ (data not shown). Thus the maximum internal glycerol level accounted for $61.9 \%$ of the total internal osmotic pressure. A similar situation was seen for cells transferred to BM + sorbitol (Fig. $5 a, b$ ). The control for these two experiments (Fig. $4 b$ ) shows that only small levels of glycerol were accumulated in cells growing exponentially in BM (i.e. $<100 \mathrm{mM}$ ). These data suggest that the relationship between glycerol production, turgor regulation and growth in $S$. cerevisiae may not be as straightforward as that proposed for $Z$. rouxii by Yagi (1988). The transfer of exponentially growing cells from $\mathrm{BM}+\mathrm{NaCl}$ to fresh $\mathbf{B M}+\mathrm{NaCl}$ caused a sudden decrease in intracellular glycerol levels at $1 \mathrm{~h}$ (Fig. $6 b$ ), which was restored to the initial value within $5 \mathrm{~h}$. It may be that the loss of glycerol occurs during the lag phase, while the production of glycerol is concomitant with growth. Intracellular glycerol levels reached a similar maximum value, of $800-900 \mathrm{mM}, 12 \mathrm{~h}$ after transfer from either $\mathrm{BM}$ or $\mathrm{BM}+\mathrm{NaCl}$ to $\mathrm{BM}+\mathrm{NaCl}$ and similarly decreased at the end of exponential phase. This investigation has demonstrated that the osmotic relations of $S$. cerevisiae are complex. Since the cell cycle (Nečas, 1979) and some basic aspects of cell metabolism (Kotyk et al., 1985) are apparently not fundamentally modified in protoplasts, they provide an additional experimental system for elucidating such relations. Protoplasts regulate intracellular levels of glycerol in the absence of a cell wall and this suggests that the restoration of turgor pressure in whole cells is not the sole regulator of glycerol accumulation.

This research was supported by the Natural Environment Research Council and the Royal Society. A.J.M gratefully acknowledges the receipt of a NERC postgraduate studentship. Thanks are also due to Miss Mandy Spetch for expert assistance.

\section{REFERENCES}

Adler, L., Blomberg, A. \& Nilsson, A. (1985). Glycerol metabolism and osmoregulation in the salttolerant yeast Debaryomyces hansenii. Journal of Bacteriology 162, 300-306.

ANDRÉ, L., Nilsson, A. \& AdLER, L. (1988). The role of glycerol in osmotolerance of the yeast Debaryomyces hansenii. Journal of General Microbiology 134, 669-677.

Arakawa, T. \& TimashefF, S. N. (1985). The stabilization of proteins by osmolytes. Biophysical Journal 47, 411-414.

ARNOLD, W. N. \& LACY, J. S. (1977). Permeability of the cell envelope and osmotic behaviour of Saccharomyces cerevisiae. Journal of Bacteriology 131, 564571.

Ben-Amotz, A. \& Avron, M. (1983). Accumulation of metabolites by halotolerant algae and its industrial potential. Annual Review of Microbiology 37, 95-119.

BorowitzKA, L. J. (1985). Glycerol and other carbohydrate osmotic effectors. In Transport Processes Iono- and Osmoregulation, pp. 437-453. Edited by
R. Gilles and M. Gilles-Baillien. Berlin: SpringerVerlag.

BorowitzKa, L. J. \& Brown, A. D. (1974). The salt relations of marine and halophilic species of the unicellular green alga, Dunaliella: the role of glycerol as a compatible solute. Archives of Microbiology 96, 37-52.

Brown, A. D. (1976). Microbial water stress. Bacteriological Reviews 40, 803-846.

Brown, A. D. (1978). Compatible solutes and extreme water stress in eukaryotic microorganisms. Advances in Microbial Physiology 7, 181-242.

Brown, A. D. \& Simpson, J. R. (1972). Water relations of sugar-tolerant yeasts: the role of intracellular polyols. Journal of General Microbiology 72, 589-591.

Brown, A. D., Mackenzie, K. F. \& Singh, K. K. (1986). Selected aspects of microbial osmoregulation. FEMS Microbiology Reviews 39, 31-36.

Clint, G. M. (1985). The investigation of stomatal ionic relations using guard cell protoplasts. II. Osmotic relations of guard cell protoplasts in short 
and long-term incubations. Journal of Experimental Botany 36, 1739-1748.

Conway, E. J. \& ARMSTRONG, W. MCD. (1961). The total intracellular concentration of solutes in yeast and other plant cells and the distensibility of the plant-cell wall. Biochemical Journal 81, 631-639.

CRAM, W. J. (1976). Negative feedback regulation of transport in cells. The maintenance of turgor, volume and nutrient supply. In Encyclopaedia of Plant Physiology, New Series, vol. 2A, pp. 284-316. Edited by U. Lüttge \& M. G. Pitman. Berlin: Springer-Verlag.

Crowe, L. M., Mouradian, R., Crowe, J. H., JACKSON, S. \& WOMERSLEY, C. (1984a). Effects of carbohydrates on membrane stability at low water activity. Biochimica et biophysica acta 769, 141-150.

Crowe, L. M., Mouradian, R., Crowe, J. H., JACKSON, S. \& WOMERSLEY, C. (1984b). Interactions of phospholipid monolayers with carbohydrates. Biochimica et biophysica acta 769, 151-159.

DAINTY, J. (1972). Plant cell-water relations: the elasticity of the cell wall. Proceedings of the Royal Society of Edinburgh A70, 89-93.

DAINTY, J. (1976). Water relations of plant cells. In Encyclopaedia of Plant Physiology, New Series, vol. 2A, pp. 12-35. Edited by U. Lüttge \& M. G. Pitman. Berlin: Springer-Verlag.

EdGley, M. \& Brown, A. D. (1983). Yeast water relations: physiological changes induced by solute stress in Saccharomyces cerevisiae and Saccharomyces rouxii. Journal of General Microbiology 129, 34533463.

GADD, G. M. (1988). Carbon nutrition and metabolism. In Physiology of Industrial Fungi. Edited by D. R. Berry. Oxford: Blackwell Scientific Publications (in the Press).

GadD, G. M., Chudek, J. A., Foster, R. \& Reed, R. H. (1984). The osmotic responses of Penicillium ochro-chloron: changes in internal solute levels in response to copper and salt stress. Journal of General Microbiology 130, 1969-1975.

GadD, G. M., Chalmers, K. \& Reed, R. H. (1987). The role of trehalose in dehydration resistance of Saccharomyces cerevisiae. FEMS Microbiology Letters 48, 249-254.

GuSTAFFSON, L. (1979). The ATP pool in relation to the production of glycerol and heat during growth of the halotolerant yeast Debaryomyces hansenii. Archives of Microbiology 120, 15-23.

Hellebust, J. A. (1976). Osmoregulation. Annual Review of Plant Physiology 27, 485-505.

HockING, A. D. (1986). Effects of water activity and culture age on the glycerol accumulation patterns of five fungi. Journal of General Microbiology 132, 269275.

INDGE, K. J. (1968). Metabolic lysis of yeast protoplasts. Journal of General Microbiology 51, 433-440.

JENNINGS, D. H. (1983). Some aspects of the physiology and biochemistry of marine fungi. Biological Reviews $58,423-459$.

JenNings, D. H. (1984). Polyol metabolism in fungi. Advances in Microbial Physiology 25, 149-193.

Kotyk, A., Michaljaničová, D., Struzinsky, R., BaRYSHNIKoVA, L. M. \& SYCHROVÁ, H. (1985). Absence of glucose-stimulated transport in yeast protoplasts. Folia microbiologica 30, 110-116.
Larsen, P. I., Sydnes, L. K., Landfald, B. \& Strøm, A. R. (1987). Osmoregulation in E. coli by accumulation of organic osmolytes: betaines, glutamic acid and trehalose. Archives of Microbiology 147, 1-7.

Le Rudulier, D., Strøm, A. R., Dandekar, A. M., SMith, L. T. \& VAlentine, R. C. (1984). Molecular biology of osmoregulation. Science 224, 1064-1068.

LEVIN, R. L. (1979). Water permeability of yeast cells at sub-zero temperatures. Journal of Membrane Biology 46, 91-124.

Low, P. S. (1985). Molecular basis of the biological compatibility of nature's solutes. In Transport Processes - Iono- and Osmoregulation, pp. 469-477. Edited by R. Gilles \& M. Gilles-Baillien. Berlin: Springer-Verlag.

MACKAY, M. A., Norton, R. S. \& Borowitzka, L. J. (1984). Organic osmoregulatory solutes in cyanobacteria. Journal of General Microbiology 130, $2177-$ 2191.

Measures, J. C. (1975). The role of amino acids in osmoregulation of non-halophilic bacteria. Nature, London 257, 398-400.

Morris, G. J., Winters, L., Coulson, G. E. \& ClaRKe, K. J. (1986). Effect of osmotic stress on the ultrastructure and viability of the yeast Saccharomyces cerevisiae. Journal of General Microbiology 132, 2023-2034.

Munns, R., Greenway, H. \& Kirst, G. O. (1983). Halotolerant eukaryotes. In Encyclopaedia of Plant Physiology, New Series, vol. 12C, pp. 60-131. Edited by O. L. Lange, P. S. Nobel, C. B. Osmond \& H. Ziegler. New York: Springer-Verlag.

NEČAS, O. (1979). Regeneration of protoplasts. In Advances in Protoplast Research, Proceedings of the 5th International Protoplast Symposium, pp. 151-161. Edited by L. Ferenczy \& G. L. Farkas. Oxford: Pergamon Press.

NoBeL, P. S. (1983). Biophysical Plant Physiology and Ecology. San Francisco: W. H. Freeman.

ONISHI, H. (1963). Osmophilic yeasts. Advances in Food Research 12, 53-94.

PANEK, A. D. (1985). Trehalose metabolism and its role in Saccharomyces cerevisiae. Journal of Biotechnology 3, 121-130.

Quain, D. E. \& Boulton, C. A. (1987). Growth and metabolism of mannitol by strains of Saccharomyces cerevisiae. Journal of General Microbiology 133, 1675 1684.

REED, R. H. (1984). Use and abuse of osmoterminology. Plant, Cell and Environment 7, 165-170.

ReEd, R. H., ChUdeK, J. A., Foster, R. \& Stewart, W. D. P. $(1984 a)$. Osmotic adjustment in cyanobacteria from hypersaline environments. Archives of Microbiology 138, 333-337.

REED, R. H., RICHARDSON, D. L., WARR, S. R. C. \& STEWART, W. D. P. (1984b). Carbohydrate accumulation and osmotic stress in cyanobacteria. Journal of General Microbiology 130, 1-4.

REED, R. H., Richardson, D. L. \& Stewart, W. D. P. (1985). $\mathrm{Na}^{+}$uptake and extrusion in the cyanobacterium Synechocystis PCC 6714 in response to hypersaline treatment: evidence for transient changes in plasmalemma $\mathrm{Na}^{+}$permeability. Biochimica et biophysica acta 814, 347-355.

Reed, R. H., Chudek, J. A., Foster, R. \& Gadd, G. M. (1987). Osmotic significance of glycerol accu- 
mulation in exponentially growing yeasts. Applied and Environmental Microbiology 53, 2119-2123.

VREELAND, R. H. (1987). Mechanisms of halotolerance in microorganisms. CRC Critical Reviews in Microbiology 14, 311-356.

Wethered, J. M., Metcalfe, E. C. \& Jennings, D. H. (1985). Carbohydrate metabolism in the fungus Dendryphiella salina. VIII. The contribution of polyols and ions to the mycelial solute potential in relation to the external osmoticum. New Phytologist 101, 631-649.

WhITE, C. \& GADD, G. M. (1987). The uptake and cellular distribution of zinc in Saccharomyces cerevisiae. Journal of General Microbiology 133, 727-737.

Wolf, A. V., Brown, M. G. \& Prentiss, P. G. (1979).

Concentrative properties of aqueous solutions: conversion tables, p. D227-276. In CRC Handbook of Chemistry \& Physics, 60th edn. Edited by R. C. Weast. Palm Beach, Florida: CRC Press.

YAGI, T. (1988). Intracellular levels of glycerol necessary for initiation of growth under salt-stressed conditions in a salt tolerant yeast, Zygosaccharomyces rouxii. FEMS Microbiology Letters 49, 25-31. 